\section{International Scientific Journal Theoretical \& Applied Science}

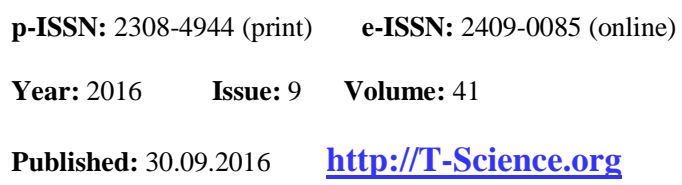

SECTION 31. Economic research, finance, innovation, risk management.

\section{B.S. Suleimenov}

Master of economical science., Kazakh Engineering and Pedagogical University of Nations Friendship

A. Dildabekova

Master of economical science., Kazakh Engineering and Pedagogical University of Nations Friendship

Aigul Kuanyshevna Kupesheva
Candidate of economical science
Chief of department of Kazakh
Engineering and Pedagogical
University of Nations Friendship

Ersultan Zhomartovich Shalkhar Muster student of Kazakh Engineering and Pedagogical University of Nations Friendship

Nurlan Muhtarovich Batyrbaev Candidate of law science, professor Vice president of International Kazakh-

Turkish University after H.A.Yessevi

Erkin Shazhievich Dusipov

Doctor of law science, professor Zhetysu state University after I.Zhansugurov

Yernar Sailaubekovich Shalkharov Master of law, economics, bachelor of biology Corresponding member of Theoretical and Applied Science Academy. General director of BeinAgroIndustries LTD. yernar_shalkharov@bk.ru

\title{
THE CORRUPTION OFFENCE NATURE IN THE REPUBLIC OF KAZAKHSTAN IN COMPLIANCE WITH CRIMINAL CODE OLD EDITION OF THE REPUBLIC OF KAZAKHSTAN INTERACTION WITH THE NEW COURSE OF THE CORRUPTION OFFENCES HUMANIZATION: COMPARATIVE APPROACH
}

Abstract: The corrupt legislation in the Republic of Kazakhstan has key value in upgrade of criminal system and in functioning of the state apparatus of the Republic that is one of the major sectors in enhancement of criminal policy of the Republic of Kazakhstan in general. Therefore, in case of well developed corruption classification system crimes and accurately systematized order of prescribed punishments there is probability of increase in overall performance not only state bodies, local government bodies, divisions of executive system, but also commercial and non-commercial legal entities as socially dangerous acts of corruption nature have universal application.

Key words: corrupt legislation, Kazakhstan, government.

Language: English

Citation: Suleimenov BS, Dildabekova A, Kupesheva AK, Shalkhar EZ, Batyrbaev NM, Dusipov ES, Shalkharov YS (2016) THE CORRUPTION OFFENCE NATURE IN THE REPUBLIC OF KAZAKHSTAN IN COMPLIANCE WITH CRIMINAL CODE OLD EDITION OF THE REPUBLIC OF KAZAKHSTAN INTERACTION WITH THE NEW COURSE OF THE CORRUPTION OFFENCES HUMANIZATION: COMPARATIVE APPROACH. ISJ Theoretical \& Applied Science, 09 (41): 162-165. 


\begin{tabular}{|c|c|c|c|c|c|c|}
\hline Impact Factor: & $\begin{array}{l}\text { ISRA (India) } \\
\text { ISI (Dubai, UAF } \\
\text { GIF (Australia) } \\
\text { JIF }\end{array}$ & $\begin{array}{l}=1.344 \\
=0.829 \\
=0.564 \\
=1.500\end{array}$ & $\begin{array}{l}\text { SIS (USA) } \\
\text { PИНЦ (Russia } \\
\text { ESJI (KZ) } \\
\text { SJIF (Morocco }\end{array}$ & $\begin{array}{l}=\mathbf{0 . 9 1 2} \\
=\mathbf{0 . 2 3 4} \\
=\mathbf{1 . 0 4 2} \\
=\mathbf{2 . 0 3 1}\end{array}$ & $\begin{array}{l}\text { ICV (Poland) } \\
\text { PIF (India) } \\
\text { IBI (India) }\end{array}$ & $\begin{array}{l}=6.630 \\
=1.940 \\
=4.260\end{array}$ \\
\hline
\end{tabular}

\section{Soi: http://s-o-i.org/1.1/TAS-09-41-28 Doi: crossef http://dx.doi.org/10.15863/TAS.2016.09.41.28}

\section{Introduction}

The main source determination corruption offenses is the Criminal Code of Kazakhstan where in articles 311 and 312 key factors of corruption crime which taking of bribe and bribery are allocated. So in compliance with part 1 of the article 311 of the Criminal Code of Kazakhstan the main subject of this crime is the person authorized on the accomplishment of the state functions or other person equated to it promoting such activity or inactivity in fact, patronized or tolerated on service. A data object of legal relationship is taking of money bribe, securities, other property, the property right benefits of property nature for itself or other persons for actions (failure to act) for benefit of the briber [1].

\section{Materials and Methods}

Therefore, as the corruption act nature it is possible to reveal illegal accomplishment of the certain actions which are in functional obligations of the person holding managerial state position for benefit of the person illegally provided to the abovestated person certain material benefits as payment for this illegal act [2]. At the same time, It should be noted that for the second person of corruption legal relationship who provided material benefits for illegal accomplishment of the state functions concerning it similar criminal liability is also provided by the provided part 1 of the article 312 Criminal Code of Kazakhstan where bribery to the person authorized on accomplishment of the state functions, or to the person equated to it personally or through the intermediary threatens with criminal liability certain measure of punishment, for perfect criminal action is provided in compliance with which [3].

However, in old edition of the Criminal Code of Kazakhstan there are defects concerning circumstances at which this crime has been committed. Instead the system of the main and additional punishments prescribed for these crimes which in effect are approximately similar is provided [4].

So, for example, in the table stated below the punishment system for these types of crimes recognized socially dangerous is provided in compliance with Criminal Code of Kazakhstan old edition

Table 1

The punishment system for crimes recognized socially dangerous.

\begin{tabular}{|l|l|c|c|}
\hline \multicolumn{1}{|c|}{ DINE } & \multicolumn{1}{c|}{ BRIBERY } & GIVING BRIDE \\
\hline \multicolumn{2}{|c|}{ PRIMARY SUNCTION } \\
\hline 1 & Penalty & From 700 till 2000 MCI & from 700 till 2000 MCI \\
\hline 2 & $\begin{array}{l}\text { Salary or other income of convict } \\
\text { for period }\end{array}$ & From 7 months till 1 month. & from 5 months till 7 months. \\
\hline 3 & Correctional labour & ------- & till 2 \\
\hline 4 & Restraint & till 5 years. & till 3 years. \\
\hline 5 & Detention. & till 5 years. & till 3 years. \\
\hline 6 & Arrest ------ & from 3 till 6 months. \\
\hline \multicolumn{3}{|l|}{ till 5 years. } \\
\hline 1 & $\begin{array}{l}\text { Divestment to hold position or } \\
\text { engage in activities }\end{array}$ & till 5 years. & Including or not. \\
\hline 2 & Property confiscation & Including or not. &
\end{tabular}

At the same time in old edition of the Criminal Code of Kazakhstan special focus was given to subjects which are illegally receiving material benefits for accomplishment of functions by authorized state bodies and also to methods in case of which corruption act was made.

The punishment system for crimes in corruption.

Table 2

\begin{tabular}{|c|c|c|c|}
\hline № & SUBJECT & $\begin{array}{c}\text { TYPE OF } \\
\text { PUNISHMENTS }\end{array}$ & PERIOD \\
\hline \multirow[t]{2}{*}{1} & \multirow[t]{2}{*}{ Official } & Violent convict & $\begin{array}{llll}\text { from } & 3 & \text { till } & 7 \\
\text { years. } & & & \end{array}$ \\
\hline & & $\begin{array}{l}\text { Deprivation of the } \\
\text { right to occupy }\end{array}$ & till 7 years. \\
\hline
\end{tabular}

ISPC Global Applied Research, 


\begin{tabular}{|c|c|c|c|c|c|c|}
\hline Impact Factor: & $\begin{array}{l}\text { ISRA (India) } \\
\text { ISI (Dubai, UAE } \\
\text { GIF (Australia) } \\
\text { JIF }\end{array}$ & $\begin{array}{l}=1.344 \\
=0.829 \\
=0.564 \\
=1.500\end{array}$ & $\begin{array}{l}\text { SIS (USA) } \\
\text { PИНЦ (Russia) } \\
\text { ESJI (KZ) } \\
\text { SJIF (Morocco) }\end{array}$ & $\begin{array}{l}=0.912 \\
=0.234 \\
=1.042 \\
=2.031\end{array}$ & $\begin{array}{l}\text { ICV (Poland) } \\
\text { PIF (India) } \\
\text { IBI (India) }\end{array}$ & $\begin{array}{l}=6.630 \\
=1.940 \\
=4.260\end{array}$ \\
\hline
\end{tabular}

\begin{tabular}{|c|c|c|c|}
\hline & & $\begin{array}{l}\text { certain positions or } \\
\text { engage in certain } \\
\text { activities }\end{array}$ & \\
\hline & & $\begin{array}{l}\text { Property } \\
\text { confiscation. }\end{array}$ & including \\
\hline 2 & Person hold major public position & Violent convict & 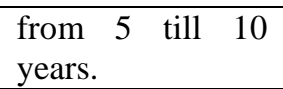 \\
\hline & & $\begin{array}{l}\text { Divestment to hold } \\
\text { position or engage } \\
\text { in activities }\end{array}$ & till 7 years. \\
\hline & & $\begin{array}{l}\text { Property } \\
\text { confiscation. }\end{array}$ & Including \\
\hline № & METHOD & PENAI & LTY \\
\hline 1 & Extort & $\begin{array}{l}\text { Violent convict } 7 \\
\text { confiscation of proper }\end{array}$ & $\begin{array}{lll}-12 & \text { years with } \\
\text { tty } & & \\
\end{array}$ \\
\hline 2 & group of persons by previous concert or organized group & $\begin{array}{ll}\text { Violent } & \text { convict } 7 \\
\text { confiscation of proper }\end{array}$ & $\begin{array}{lll}-12 & \text { years } & \text { with } \\
\text { ity } & & \\
\end{array}$ \\
\hline 3 & Grand larceny & $\begin{array}{l}\text { Violent convict } 7 \\
\text { confiscation of proper }\end{array}$ & $\begin{array}{lll}7-12 & \text { years with } \\
\text { tty }\end{array}$ \\
\hline 4 & Grand larceny & $\begin{array}{ll}\text { Violent } & \text { convict } 7 \\
\text { confiscation of proper }\end{array}$ & $\begin{array}{lll}-12 & \text { years } & \text { with } \\
\text { ity } & & \\
\end{array}$ \\
\hline 5 & Unlimited number & $\begin{array}{l}\text { Violent convict } 7 \\
\text { confiscation of proper }\end{array}$ & $\begin{array}{lll}-12 & \text { years } & \text { with } \\
\text { ity } & & \\
\end{array}$ \\
\hline
\end{tabular}

At the same time in the 311 article note concerning taking of bribe accurate definition of the sizes of large and especially large sizes of bribe is given. Thus as the large amount of taking of a bribe the amount of money, cost of securities, other property or benefits of property nature exceeding five hundred monthly settlement indicators [5] is recognized. As for the sizes of especially large amount especially large size of a bribe the amount of money, cost of securities, other property or benefit of property nature which exceed two thousand monthly settlement indicators [6] are recognized. At the same time accurate determination is also applicable to insignificance of the sizes as for example in the note of the same article it is provided that isn't a crime owing to insignificance and is pursued in a disciplinary or administrative order obtaining for the first time by the person authorized on accomplishment of the state functions, or equated to it by the person of property, the right to property or other property benefit as a gift in the absence of the preliminary arrangement for earlier made lawful acts (failure to act) if the cost of a gift didn't exceed two monthly settlement indicators [7].

\section{Conclusion}

Thus, it is possible to establish the fact with which into accord in old edition of the Criminal Code of Kazakhstan clear measures and criteria with which in compliance it is possible to be guided in case of execution by authorized bodies of internal affairs of policy on execution of corruption crimes that can't be told about other article - the 312th bribery are adequately brought. Concerning this article it is necessary to introduce amendments and in more detail to consider circumstances under which the crime was committed.

\section{Background.}

For a whole competent it is actual to notice that all issues in articles were formulated from the surveys of BeinAgroIndustries LTD. Also, it is important to mention together work of two university staff: Kazakh Engineering and Pedagogical University of Nations Friendship and International Kazakh-Turkish University after Khoga Akhmet Yassavi. In case of novelty, p.t.value the main author is the last in the list of authors.

\section{References:}

1. (2016) Criminal Code of the Republic of Kazakhstan. 


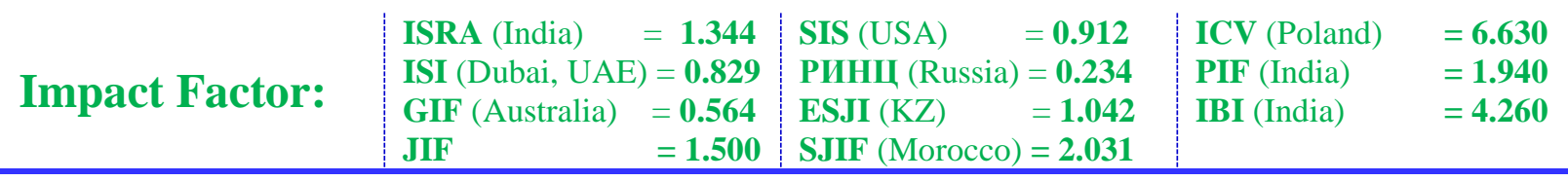

3. (1998) "Kazakhstanskaya Pravda". - 1998. - 21 of September.

4. (1998) "Kazakhstanskaya Pravda". - 1998. - 21 of November.

5. Alison Jamieson (1997) Mafia rules the world // International organized crime. - Internationale Politik. - 1997. - № 12. - pp. 30.
6. Emmanuel Sivan (1997) Radical Islam // Reasons and consequences of terrorist violence. - International Politik. - 1997. - № 8. pp. 6 - 15.

7. Kaufmann D. Siegelbaum P (1996) Privatization and corruption in Transition Economies // Journal of International Affairs. Vol 50 № 2, winter 1996, pp. 423. 